University for Business and Technology in Kosovo

UBT Knowledge Center

UBT International Conference

2017 UBT International Conference

Oct 28th, 4:00 PM - 5:30 PM

\title{
The Role of English Language - Connection for all Ethnicities in Kosovo
}

Feride Lohaj

South East European University, f121370@seeu.edu.mk

Follow this and additional works at: https://knowledgecenter.ubt-uni.net/conference

Part of the Education Commons

\section{Recommended Citation}

Lohaj, Feride, "The Role of English Language - Connection for all Ethnicities in Kosovo" (2017). UBT International Conference. 111.

https://knowledgecenter.ubt-uni.net/conference/2017/all-events/111

This Event is brought to you for free and open access by the Publication and Journals at UBT Knowledge Center. It has been accepted for inclusion in UBT International Conference by an authorized administrator of UBT Knowledge Center. For more information, please contact knowledge.center@ubt-uni.net. 


\title{
The Role of English Language - Connection for all Ethnicities in Kosova
}

\author{
Feride Lohaj \\ South East European University, \\ Faculty of Language, Culture and Communication, \\ Tetovo, Macedonia \\ f121370@ seeu.edu.mk
}

\begin{abstract}
English Language in Kosova has expanded from its previous function as a sign of prestige and necessity for people who want to get educated or work abroad, to the main tool of communication between the two ethnicities, Albanian and Serb, still distanced from each other. In this study, the results determine students' preferences, their level of interculturalism and English language proficiency. This study also proof hypothesis that all students from particular communities have low level of intercultural competence, they have similar preferences, but focusing on their ethnicity, furthermore, their level of English language proficiency is similar. This study covers high school students from various cities in Kosova. There are 175 Albanian, 89 Serb, 7 Turkish students.
\end{abstract}

Key words: Multiculturalism, Interculturalism, English Language, Cultural Differences

\section{Introduction}

Due the hostility between the Albanians and Serbs who live in Kosova there is no communication between each other. There are some contacts but mostly business kinds and they stopped when the deal is done. Multiculturalism is the main principle of social organization of all ethnicities that live in Kosova. Serbs and Albanians live in parallel 'worlds'. They have parallel governing, parallel education system; parallel health care, though officially both communities accepted Kosova government, participated in elections held in Kosova and chose their representatives Though, there are very few attempts of communication, at workplace, seminars and meetings organized by foreign NGOs the youth of both ethnicities communicate in English language. English Language in these regions has expanded from its previous function as a sign of prestige and necessity for people who want to get educated or work abroad, to the main tool of communication between the two ethnicities still distanced from each other. In order to increase intercultural level of the youth and since the English language is the only communication tool between Albanian and Serb youth, the English language students' books should contain a lot of intercultural elements so that they can learn to know each other and to find mutual points of interest in order to develop communication between each other. 


\section{Literature Review}

Due the differences in culture and customs applied by particular communities, the developing of intercultural competence cannot be achieved in the same manner in different countries in this region, but according to their specific features and preferences, as in this case, through the English language learning. There are several studies of interculturalism in Balkan region which can be useful for this study and can be used as guidance, but none of them can be applied as an ultimate answer.

In the article 'Intercultural Communicative English Language Teaching' (2009), Jasmina Djordjević states that "When intercultural communication is integrated, the interaction between students' native and target cultures motivates students to communicate freely in the target language without any fear of mockery because their cultural diversity is acknowledged and legitimized".

Milica B. Stefan (2005), in her paper "The inclusion of intercultural communication competence in teaching foreign languages", states that life in a multilingual and multicultural Europe requires to incorporate teaching intercultural competence in the curriculum of foreign languages at all educational levels. Trained foreign language teachers will become aware of the importance of cultural elements in language learning, they will include at least some of knowledge, skills and attitudes necessary for the acquisition of intercultural competence.

The importance of education for rising of intercultural competence and intercultural sensitivity were emphasized by Hasena Kavazović (May 2012, p3). In her article "Intercultural education as an imperative for the development of intercultural competences and intercultural sensitivity" she claims that multi-ethnicity, multiculturalism and interculturalism are reality in many societies these days. She explains that multiculturalism means a plurality of cultures on the same area. Those different cultures with different languages live next to each other.

\section{Methodology}

The study was completed by analyzing the questionnaires and tests conducted on students in seven high schools attended by Albanian, Serb and Turkish students in five towns in Kosova.

\section{The aim of the study}

The aim of this study was to find a way of increasing the level of intercultural competences of students of both communities, Albanian and Serbian.

\section{Research questions}

What is the intercultural level of students from particular communities?

$0 \quad$ What are the mutual points of interest of the youth which can be used in designing of course books?

- How can course material be designed to meet increased level of intercultural competence in a smooth way without pushing (forcing) ethnicities to create false sense of intercultural competence? 


\section{Research hypothesis}

- All students from particular communities have low level of intercultural competence. - The mutual points of interest of the students were: sport, professions, preferred places, social media.

- Designing of the course books with various features of English, Albanian, American, Serbian, Turkish, RAE and Bosnian culture will increase intercultural competence of students.

\section{Research Participants}

Research participants were students from the high schools in Ferizaj, Kamenica, Gjilani, Shterpce and Firaja. There were 175 Albanian students, 71 from $10^{\text {th }}, 77$ from $11^{\text {th }}, 27$ from $12^{\text {th }}$ grade; 89 Serb students, 28 from $1^{\text {st }}$ year, 27 from $2^{\text {nd }}$ year, 29 from $3^{\text {rd }}$ year, 5 from $4^{\text {th }}$ year; 7 Turkish students, 4 from $10^{\text {th }}, 3$ from $11^{\text {th }}$ grade

\section{Instruments}

\section{Questionnaire}

10 questions which determine students' preferences

10 questions which determine students' intercultural competence

\section{Tests}

Test 1 for $10^{\text {th }}$ grade and $1^{\text {st }}$ year,

Test 2 for $11^{\text {th }}$ grade and $2^{\text {nd }}$ year,

Test 3 for $12^{\text {th }}$ grade, $3^{\text {rd }}$ and $4^{\text {th }}$ year.

\section{Findings/Discussion}

The questionnaire and tests were analyzed and the findings were presented below.

From the students' questionnaire part one:

The first question "How old are you?" (Table 1 and 2) was used to show us the range of ages the students are. According to answers, the age range is from 14 to 19 for all schools years. It also determines the gender of the students, and it shows that in all grades there is larger number of female students than male students. 
Table 1. Students' Ages

\begin{tabular}{|c|c|c|c|c|}
\hline Age & $\begin{array}{c}\text { 10th and 1st } \\
\text { Year } \\
\text { Students }\end{array}$ & $\begin{array}{c}\text { 11th and 2nd } \\
\text { Year students }\end{array}$ & $\begin{array}{c}\text { 12th, 3rd Year } \\
\text { Students }\end{array}$ & 4th Year Students \\
\hline $\mathbf{1 4}$ & 2 & & & \\
\hline $\mathbf{1 5}$ & 36 & & 3 & \\
\hline $\mathbf{1 6}$ & 64 & 44 & 40 & 5 \\
\hline $\mathbf{1 7}$ & 2 & 55 & 16 & \\
\hline $\mathbf{1 8}$ & & 2 & 1 & \\
\hline $\mathbf{1 9}$ & & & & \\
\hline
\end{tabular}

Table 2. Students' Gender

\begin{tabular}{|l|lcc|cc|cc|}
\hline & $\begin{array}{l}\text { 10th and 1st Year } \\
\text { Students }\end{array}$ & $\begin{array}{l}\text { 11th and 2nd Year } \\
\text { Students }\end{array}$ & $\begin{array}{l}\text { 12th and 3rd Year } \\
\text { Students }\end{array}$ & 14 \\
\hline Male & & 31 & & 39 & & 20 \\
\hline Female & & 48 & & 41 & & 14 \\
\hline
\end{tabular}

Answers on the second question "What would you like to work after finishing the school?" (Table 3) showed that professions the students prefer are in field of education, health care, information technique and construction. Also the third question, "What is your hobby?", (Table 3) showed that most students practice listening to the music, sports, arts, writing. Their favourite groups or singers are from their own community.

Table 3. Favourite Professions, Hobbies, Music Groups and Singers

\begin{tabular}{|c|c||c|c||c|c|}
\hline Professions & Students & Hobbies & Students & $\begin{array}{c}\text { Groups } \\
\text { or } \\
\text { Singers }\end{array}$ & Students \\
\hline Education & $19.63 \%$ & Music & $10.37 \%$ & OTR & $4.81 \%$ \\
\hline Health Care & $18.52 \%$ & Sports & $25.56 \%$ & $\begin{array}{c}\text { Dua } \\
\text { Lipa }\end{array}$ & $3.33 \%$ \\
\hline Information Technique & $4.07 \%$ & Arts & $4.81 \%$ & Rihanna & $3.33 \%$ \\
\hline Construction & $2.96 \%$ & Writing & $1.48 \%$ & Noizy & $2.96 \%$ \\
\hline Justice system & $1.85 \%$ & Sleeping & $1.48 \%$ & $\begin{array}{c}\text { Ledri } \\
\text { Vula }\end{array}$ & $2.96 \%$ \\
\hline
\end{tabular}

Answer on the fifth question "What is your

favourite sport?" (Table 4) showed that football, volleyball and basketball are the most favourite sports and the answer on the sixth question "What places would you visit?" (Table 4) showed that students prefer to visit developed countries/places as USA, France, Dubai, Italy and Germany and on the question "If you were a president, what would you change?" (Table 4) students saw need for change in everything, more specific in economy, living conditions education. 
Table 4. Favourite Sports, Places and What Changes Need to be Done

\begin{tabular}{|c|c||c|c||c|c|}
\hline Sports & Students & Places & Students & Need changes & Students \\
\hline Football & $34.40 \%$ & USA & $35.92 \%$ & Everything & $21.48 \%$ \\
\hline Volleyball & $30.00 \%$ & France & $29.25 \%$ & Economy & $21.11 \%$ \\
\hline Basketball & $21.11 \%$ & Dubai & $13.70 \%$ & $\begin{array}{c}\text { Living } \\
\text { Conditions }\end{array}$ & $18.14 \%$ \\
\hline Tennis & $2.59 \%$ & Italy & $13.70 \%$ & Education & $17.77 \%$ \\
\hline Swimming & $2.22 \%$ & Germany & $11.48 \%$ & & \\
\hline
\end{tabular}

Answers on the question eight, "If you could, in what century would you live?" (Table 5), show that majority of students would live in the past; other students would live in future, but at least would live in current century. Answer on the questions "Which social networks you frequently use?"(Table 5) shows that youth are using the same social network, but TV programs were watched according to their ethnicity. Except $5.92 \%$ of Albanian students watched German TV programs.

Table 5. Preferred Century to Live in, Social Media and TV Programs Mostly Used

\begin{tabular}{|c|c||c|c||c|c|}
\hline $\begin{array}{c}\text { Century } \\
\text { you would } \\
\text { live in }\end{array}$ & Students & Social Media & Students & TV Programs & Students \\
\hline $\begin{array}{c}\text { Before this } \\
\text { Century }\end{array}$ & $38.88 \%$ & Facebook & $38.51 \%$ & RTS & $5.93 \%$ \\
\hline $\begin{array}{c}\text { This } \\
\text { Century }\end{array}$ & $28.88 \%$ & Instagram & $65.55 \%$ & $\begin{array}{c}\text { Prva Srpska } \\
\text { Televizija }\end{array}$ & $6.66 \%$ \\
\hline $\begin{array}{c}\text { After this } \\
\text { Century }\end{array}$ & $30.37 \%$ & Snap Chat & $25.55 \%$ & PINK & $5.55 \%$ \\
\hline No Answer & $7.03 \%$ & What's Up & $5.92 \%$ & Explorer & $4.81 \%$ \\
\hline & & Twitter & $3.70 \%$ & RTL & $5.92 \%$ \\
\hline & & Viber & $8.88 \%$ & FOX & $4.44 \%$ \\
\hline
\end{tabular}

\section{Students Questionnaire Part Two}

After analyzing the answers from questionnaire and according to Bennet (2007) the stages of interculturalism of the students were:

$\begin{array}{ll}* & \text { Albanian students: Acceptance; } \\ & \text { Serb students: Defense; } \\ & \text { Turk students: Acceptance. }\end{array}$

\section{Students' test}

Results of students' tests are presented below:

Table 6. Results of Albanian Students' Tests 


\begin{tabular}{|c|c|c|c|}
\hline \multicolumn{4}{|c|}{ Albanian Students } \\
\hline Grade & $\mathbf{1 0}^{\text {th }}$ grade & $\mathbf{1 1}^{\text {th }}$ grade & $\mathbf{1 2}^{\text {th }}$ grade \\
\hline 1 & $1.25 \%$ & $29.90 \%$ & $14.82 \%$ \\
\hline 2 & $21.25 \%$ & $46.70 \%$ & $29.63 \%$ \\
\hline 3 & $46.25 \%$ & $19.50 \%$ & $37.03 \%$ \\
\hline 4 & $31.25 \%$ & $3.90 \%$ & $18.52 \%$ \\
\hline 5 & & & \\
\hline
\end{tabular}

From the

Table 6 , it can be seen that the best results achieved students of the $10^{\text {th }}$ grade and the worst students of the $11^{\text {th }}$ grade.

Table 7. Results of Turk Students' Tests

\begin{tabular}{|c|c|c|c|}
\hline \multicolumn{5}{|c|}{ Turk Students } \\
\hline Grades & $\mathbf{1 0}^{\text {th }}$ grade & $\mathbf{1 1}^{\text {th }}$ grade & $\mathbf{1 2}^{\text {th }}$ grade \\
\hline $\mathbf{1}$ & & & \\
\hline $\mathbf{2}$ & & $100 \%$ & \\
\hline $\mathbf{3}$ & $75 \%$ & & \\
\hline $\mathbf{4}$ & $25 \%$ & & \\
\hline $\mathbf{5}$ & & & \\
\hline
\end{tabular}

From the Table 7, it can be seen that the best results achieved students of the $10^{\text {th }}$ grade and the worst students of the $11^{\text {th }}$ grade. Students of the $12^{\text {th }}$ grade did not take part in the testing.

Table 8. Results of Serb Students' Tests

\begin{tabular}{|c|c|c|c|}
\hline \multicolumn{4}{|c|}{ Serb Students } \\
\hline Grades & $\mathbf{1}^{\text {st }}$ Year & $\mathbf{2}^{\text {nd }}$ Year & $\mathbf{3}^{\text {rd }}$ and $\mathbf{4}^{\text {th }}$ Year \\
\hline $\mathbf{1}$ & $3.70 \%$ & $32.15 \%$ & \\
\hline $\mathbf{2}$ & $37.00 \%$ & $64.28 \%$ & $60 \%$ \\
\hline $\mathbf{3}$ & $59.30 \%$ & $3.57 \%$ & $40 \%$ \\
\hline $\mathbf{4}$ & & & \\
\hline $\mathbf{5}$ & & & \\
\hline
\end{tabular}

From the Table 8 , it can be seen that the best results achieved students of the $3^{\text {rd }}$ and $4^{\text {th }}$ year and the worst students of the $2^{\text {nd }}$ year. 
Table 9. Comparison of Students Tests According to Their Ethnicity

\begin{tabular}{|c|r|r|r|}
\hline Grades & Albanian Students & Serb Students & Turk Students \\
\hline $\mathbf{1}$ & $15.32 \%$ & $14.42 \%$ & \\
\hline $\mathbf{2}$ & $32.53 \%$ & $53.76 \%$ & $50 \%$ \\
\hline $\mathbf{3}$ & $27.59 \%$ & $34.29 \%$ & $37.50 \%$ \\
\hline $\mathbf{4}$ & $17.89 \%$ & & $12.50 \%$ \\
\hline $\mathbf{5}$ & & & \\
\hline
\end{tabular}

On the table 9, it can be seen that the results of the students' tests show clearly that there is a small difference between results of Serb and Turk students while Albanian students have the lowest result.

\section{Conclusion / implications}

The questionnaires and tests were carefully analyzed and compared. The findings are clear and they show undoubtedly that:

- The first hypothesis proven - All students from particular communities have low level of intercultural competence.

- The second hypothesis proven - The mutual points of interest of the students was: sport, professions, preferred places, social media.

- The third hypothesis proven - Designing of the course books with various features of English, Albanian, American, Serbian, Turkish, RAE and Bosnian culture will increase intercultural competence of students. They have many mutual interests, except they all prefer their own music and watch their own TV programs. This fact can be used to create texts which will show their diversity in interesting way.

\section{Limitations and Recommendations}

In this study, there were questioned only high school students in several schools. Findings can be taken in consideration but further research in other towns is needed in order to enforce current findings.

Since it is not real to expect that this research can manage to move both ministries of education, Kosova and Serbian to design mutual student books this finding can be useful for designing the script used as Appendix to current student books.

\section{References}

1. Djordjević, J. (2009). Intercultural Communicative English Language Teaching. ICIS News, Volume 7-2 . Retrieved from: http://www.tesol.org/read-and-publish/newslettersother-publications/interest-section-newsletters/icis-newsletter/2011/10/26/icis-newsvolume-7-2-(july-2009)

2. Kavazovic, H. (2012). Interkulturalno obrazovanje kao imperativ za razvoj interkulturalnih kompetencija i interkulturalne osjetljivosti. Filozofski fakultet. Sarajevo. 
Retrieved from: https://www.academia.edu/3818881/ Interkulturalno_obrazovanje_kao_ imperativ_za_razvoj_interkulturalnih_kompetencija_i_interkulturalne_osjetljivosti

3. Štefan, M. (2005). Uključivanje interkulturalne komunikacijske kompetencije u poučavanje stranih jezika. (The inclusion of intercultural communication competence in teaching foreign languages),OŠ. Dugave. Zagreb. Retrieved from http://hpkznapredak.hr/wp-content/uploads/sites/387/2015/08/Engleski_prvi_jezik_1-8radna_verzija.pdf

4. Bennet, M. (2007). Based concepts of intercultural communication. Intercultural Press. Retrieved from http://www.idrinstitute.org/allegati/IDRI_t_Pubblicazioni/6/FILE_Documento.pdf 